\title{
Breeding and Rearing of Japanese Field Voles (Microtus montebelli Milne-Edwards) and Hungarian Voles (Microtus arvalis Pallas) as New Herbivorous Laboratory Animal Species
}

\author{
Hiroshi KUDO and Yoshio OKI \\ Department of Physiological Chemistry, Nippon Veterinary and Zootechnical \\ College, 1-7-1 Kyonancho, Musashino, Tokyo 180, Japan
}

(Received for publication: May 23, 1981)

\begin{abstract}
Microtus species are very useful as experimental small animals with herbivorous characteristics. In this report, to approach establishment of the use of Japanese field voles (M. montebelli) and Hungarian voles (M. arvalis) as experimental animals, the biological characteristics, breeding methods and reproductive performance of these animal species were comparatively investigated. The number of chromosomes of $M$. arvalis is $2 n=46$, differing from those of $M$. montebelli, $2 n=30$. The breeding and reproduction of the Microtus species were relatively easily accomplished in the laboratory, by giving high fiber-containing rations. These animals prove to be polyestrous and showed postpartum estrous on the day of parturition. In the breeding by the continuous mating of the same pairs, there was little or no delay in implantation due to lactation, especially in $M$. arvalis resulting in continuous birth at intervals of 20 to 21 days. On examination of vaginal smears, Japanese field voles ( $M$. montebelli) did not show any definite pattern whereas 23 out of 30 voles from Hungary ( $M$. arvalis) examined showed 6 - to 18-day cycles. There were remarkable differences between the Japanese voles and the Hungarian voles, both biologically and reproductively.
\end{abstract}

\section{草食性実験動物としての本邦産ハタネズミ (Microtus montebelli Milne-Edwards) とハンガリ一産ハタネズミ(Microtus arvalis Pallas) の育成および繁殖について}

\section{工 藤 博 · 大木与志雄}

日本獣医畜産大学生理化学教室

\footnotetext{
八タネズミ(Microtus species) はゲッ歯目一ネズミ 科一ハタネズミ亜科一八タネズミ属に属する小型の動物 である。この動物は草食性であるために他種ネズミ類と は異なって大きな胃と盲腸を有する。とくに胃はよく発 達したU字型の複胃で, 食道のら, 腺胃および幽門胃の 三つの部分からなっており，草食に適した消化機能を有 している $[3,4,9,12,13,14,20,22,25,26]$ 。
}

著者ら[12,13,14]は，八タネズミの消化生理に抽ける
食道のらの役割を明らかにするために, 食道のら内に生 息する細菌の種類, 数を明らかにしたが, 同時にその構 成が，摄取する飼料によって影響されること，とくに高 線維含有飼料を給与した場合には, 強力な線維分解能を 有する 線維分解菌が多数存在することを認めた。さら に, 肝臓, 乳腺組織に拈ける代謝も, マウスなどいわゆ る “糖動物” とは異なる “脂酸動物” の型を示すことな どを明らかにした。 
これまで，数多くの研究者が，本種の実験動物化を試 みてきたが，その多くは，途中で挫折している。近年わ が国では, 後藤 $[5,6,7]$ が1973年から, 長野県菅平で捕 獲した本邦産ハタネズミ(M. montebelli) を中心とし て，実験動物化を試みている。

当研究室では, より繁殖能力の高い小型の草食性実験 動物の開発を目的として, 埼玉県桶川で捕獲した本邦産 八タネズミ $(2 n=30)$ の室内飼育繁殖を試み，一つの繁 殖群を確立した。またハンガリ一産由来ハタネズミ $(M$. arvalis) の分与を受け，その継代，繁殖を行い，ほぼ マウスの程度まで温順になった。これら両種の生物学的 および飼育, 繁殖上の特性を知ることは, 実験動物学上 きわめて重要であると考え, 本邦産と八ンガリ一産の両 ハタネズミを比較しながら検討を加えたので報告する。

\section{材料および方法}

1. 当研究室のハタネズミの起源

(a) 本邦産ハタネズミ (M. montebelli)：1977年, 埼 玉県桶川市の荒川河川敷にある牧草地で捕獲したものを 中心に，飼育繁殖を継続している無作為交配群。

(b) ハンガリ一産ハタネズミ (M. arvalis Pallas) [21]：1969〜1971年ハンガリーの各地で捕獲したものを 母体にハンガリーゲッ歯類生物研究所で, 兄妹交配を行 った近交 8 10世代のものを1979年 1 月, 著者がハンガ リーから持ち帰り, 当研究室で引き続き兄妹交配 ( 5 世 代）を続けている群。

2. 飼育条件

(a) 温度, 光 : 飼育温度は $18 \sim 24^{\circ} \mathrm{C}$, 照明は螢光灯を 用い，14時間明，10時間暗で飼育した $[15]$ 。

(b) ケージ，床敷：マウス一般飼育用の $210 \times 320 \times$ $135 \mathrm{~mm}$ のポリカーボネイト透明ケージ（日本クレア製） を使用し，一般飼育時は，5匹以内，繁殖時は，合 1 匹， 1 匹を収容した。また床敷は，通常カンナ屑を用 い, 繁殖期にはカンナ屑の他に,さらに乾草を巣材とし た。床換えは週 $2 \sim 3$ 回行ない, 毎回全部の床敷を取り かえた。

(c) 飼料：ウサギ, モルモット用ペレット GC-4, 草食 動物用ペレット ZC (オリエンタル醉母社製) およびへ イキューブ (方形状の圧縮干草, 米国製) を薄く刻んだ ものをそれぞれ常時給与し, 自由採食とした（1日 1 匹 あたり，およそペレット 7〜8 g，へイキューブ $3 〜 4$ $\mathrm{g}$ )。給水は給水ビンを用い，自由飲水とした。

\section{3. 開胵週齢}

出生日を 0 日として，腟開口までに要した週龄をしら べた。

4. 腔坧検査

原則として胵垢採取を午前 8 時と午後10時に，22〜30 日間行ない, 小ピペットにて腔内を蒸留水あるいは生理 食塩液で, $2 〜 3$ 回洗い, 洗滌液をスライドグラスに取 り, 室温乾燥後, メタノール固定, ギムザ染色を行ない 鏡検した $[10,11]$ 。

5. 卵子の確認

ハンガリー産ハタネズミについてのみ，腔垢中の角化 細胞消失 $48 \sim 120$ 時間後に生理食塩液で子宮を灌流し， 倒立顕微鏡で卯子の有無を確認した $[16]$ 。

6. 交配方式

原則として, 初交配を60日齢で雄 1 , 雌 1 の同居によ り行ない, 一度ペアリングをして, 妊娠, 育仔をしたも のは，全繁殖期間を通じて，同居を継続した。雌の初産 日齢を検索する場合は, 離乳直後, 成熟雄と同居させ た。

7. 精子の確認

八タネズミは出産後, 直ちに交尾をするので, 出産後 30 分〜 6 時間の倠の腟内を小ピペットを用いて, 蒸留水 で $2 \sim 3$ 回洗い, 洗條液をスライドグラスに取り, 室温 乾燥後, メタノール固定, ギムザ染色を行ない, 鏡検し た。

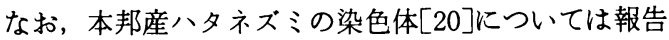
があるが，ハンガリ一産ハタネズミの染色体について は, 報告されていないので, 胎仔線維芽細胞と大腿骨 · 骨髄細胞から標本を作成して鏡検した $[8,23,24,27]$ 。

\section{成 核}

1. 外観的特性

Fig. 1 および Fig. 2 はハンガリ一産ハタネズミの写 真である。八タネズミは主として地中の孔道で生活して いて, その外観的な特徴は, マウスと比較して, 頭蓋骨 が丸く, 尾が短く, 耳も小さいことである。ハンガリー 産と本邦産の両八タネズミを比較すると，ハンガリ一産 の方が小型で，眼が大きく，色も多少黒味を带びてい る。

な怙，本邦産ハタネズミの染色体数は $2 n=30$ (Fig. 3）に対して，ハンガリ一産ハタネズミのそれは $2 n=46$ (Fig. 4)であった。

2. 新生仔の発育 1979年における当研究室の本邦産とハンガリ一産ハ夕 


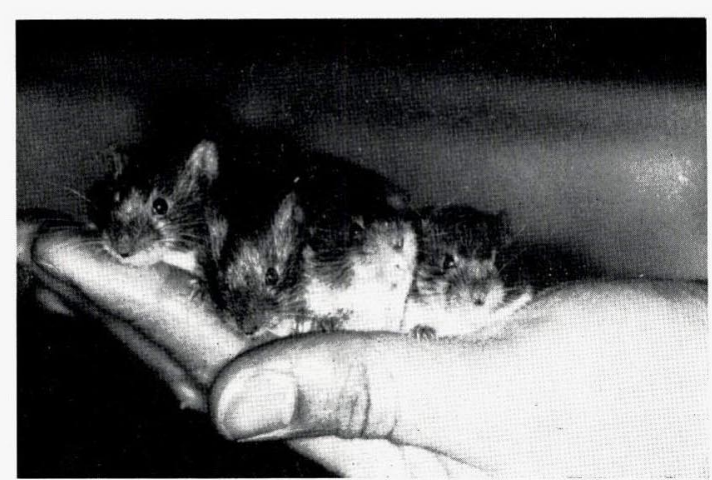

Fig. 1 Gentle Microtus arvalis Pallas

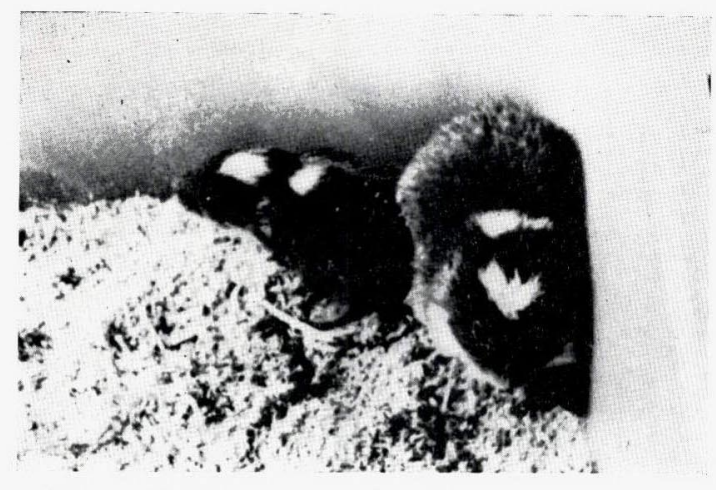

Fig. 2 White spot strain of Microtus arvalis Pallas

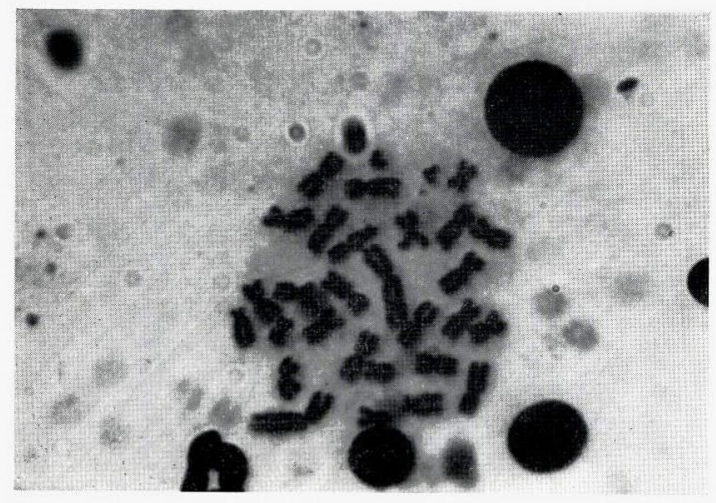

Fig, 3 Chromosomes of Microtus montebelli, $2 n=30$; Giemsa stain, $1200 \times$

ネズミの成長曲線を Fig. 5 に示した。両種とも, 雄の 方が大きい。新生仔体重は, 本邦産で平均 $2.8 \mathrm{~g}$, 八ン ガリー産では平均 $1.9 \mathrm{~g}$ であった。顕著な体重増加が涩

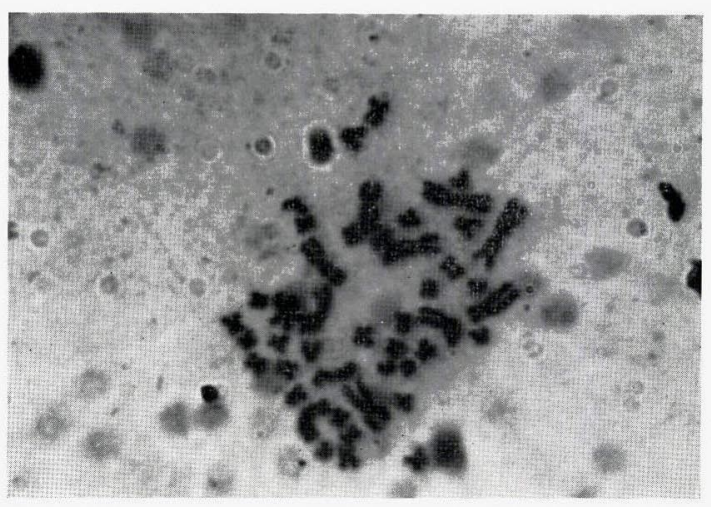

Fig. 4. Chromosomes of Microtus arvalis Pallas, $2 n=46$; Giemsa stain, $1200 \times$

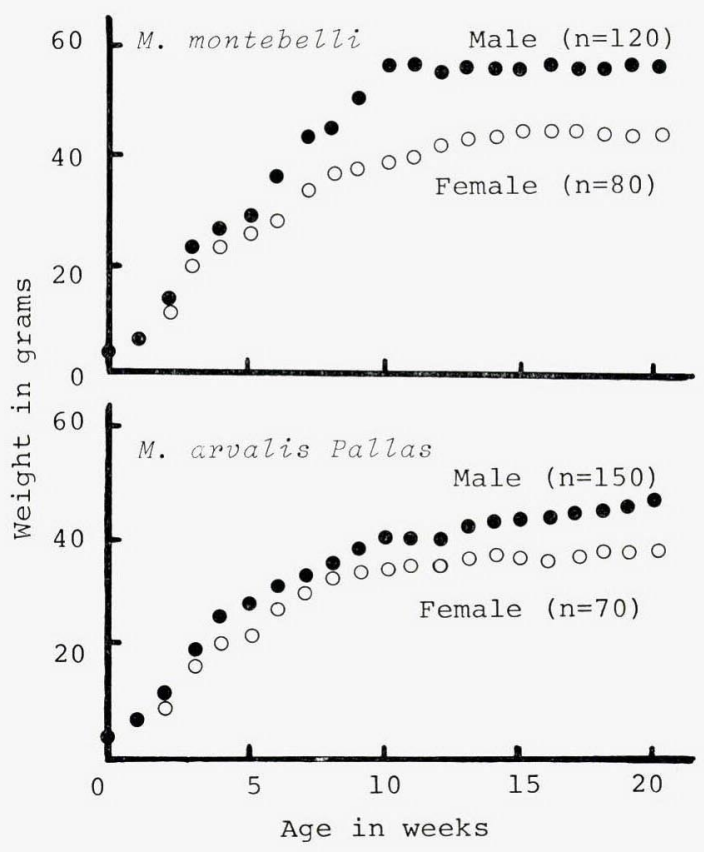

Fig. 5. Giowth curves for M. montebelli and M. arvalis Pallas in the laboratory

められるのは, 生後13〜15日からで, この動物の離乳期 にあたり，固型飼料を摄取し始める時期である。体重增 加は約10週でほぼ止まる。成長に伴ら形態的变化は, 肉 眼的には, およそ次のようであった。乳頭の観察可能 $(2 \sim 3$ 日齢雌, 4 対 $) \longrightarrow$ 発毛 $(3 \sim 4$ 日歯 $) \longrightarrow$ 開耳

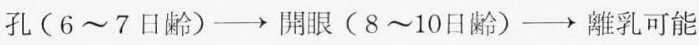
(14日秢)。採食は早いものでは 9 日秢で始まり, 離乳時 にはすでに開腟している個体もあり，極く稀ではある 
Table 1. Ages of $M$. montebelli and $M$. arvalis at time of vaginal opening

\begin{tabular}{crc}
\hline Age in weeks & $M$. montebelli & $M$. arvalis \\
2 & $3 / 63^{*}(4.8 \%)$ & $10 / 125(8 \%)$ \\
3 & $5 / 63(7.9 \%)$ & $23 / 125(18.4 \%)$ \\
4 & $30 / 63(47.6 \%)$ & $88 / 125(70.4 \%)$ \\
5 & $45 / 63(71.4 \%)$ & $95 / 125(76 \%)$ \\
6 & $48 / 63(76.2 \%)$ & $105 / 125(84 \%)$ \\
7 & $50 / 63(79.4 \%)$ & $110 / 125(88 \%)$ \\
8 & $50 / 63(79.4 \%)$ & $118 / 125(94.4 \%)$ \\
9 & $52 / 63(82.5 \%)$ & $119 / 125(95.2 \%)$
\end{tabular}

* ; No. of voles with opened vagina/No. of voles examined.
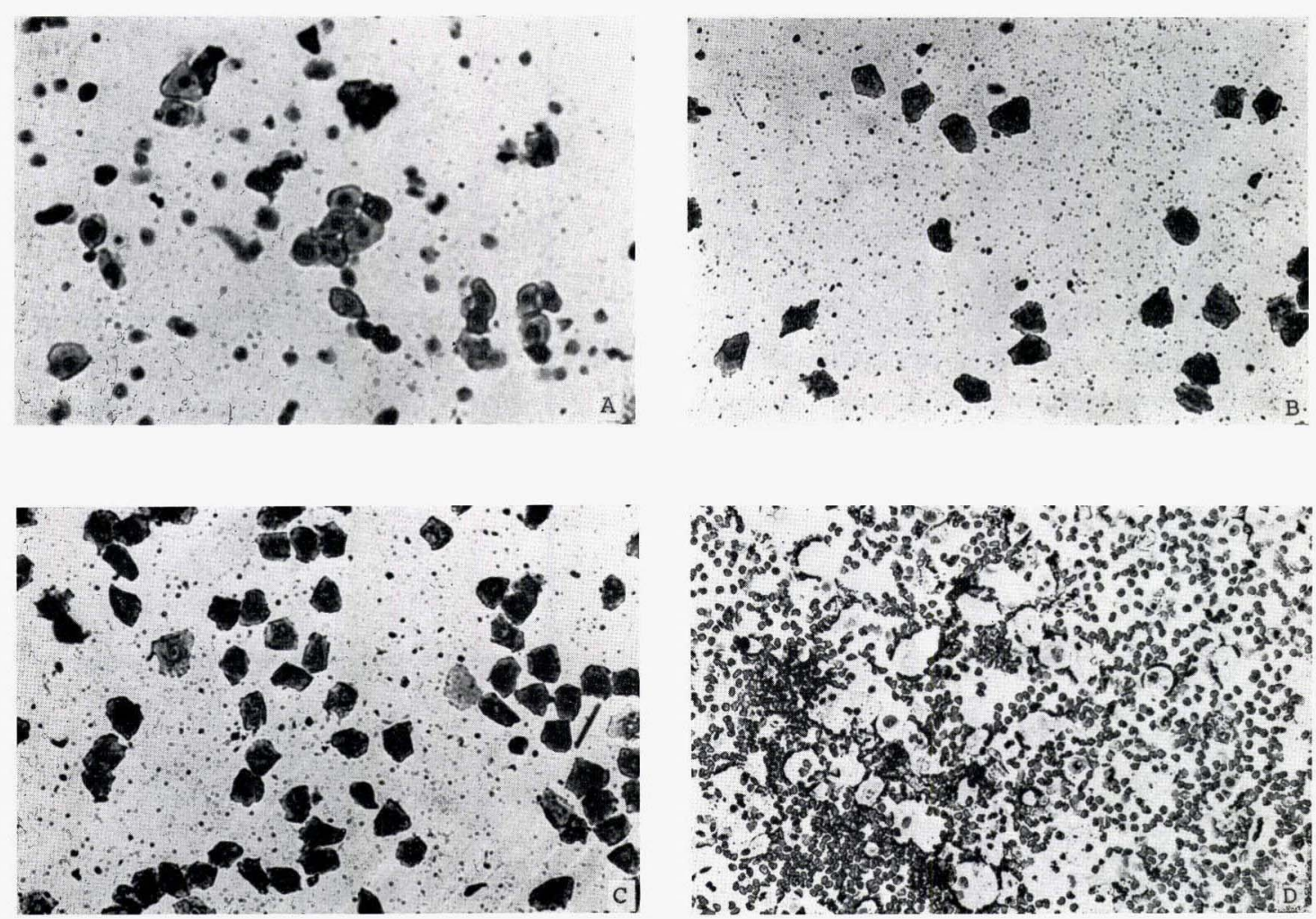

Fig. 6 Vaginal smears in Microtus arvalis Pallas
A. Proestrous stage (I). Nucleated epithelial cells can be seen. $100 \times$
B. Estrous stage (II). Note the marked cornification. $100 x$
C. Metestrous stage I (III). Numbers of cornified epitherial cells appear. 100x
D. Metestrous stage II (IV). Containing some degenerated epitherial cells and numbers of leucocytes. $100 \times$

が，ハンガリー産では生後33日目，本邦産では同35日目 こ，雄親との交配によるものと思われる初産の認められ た個体もあった。このように八タネズミの成長に伴ら形 3. 開腔

Table 1 と本邦産とハンガリ一産八タネズミの開腔す る週秢を示した。本邦産では63匹中 3 匹 $(4.8 \%)$, ハン

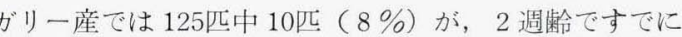
開腔していた。開胺は，ハンガリ一産の方が早く， 4 週 秢で70\%が開腔するのに対して，本邦産では約 $48 \%$ であ った。また本邦産では，9週龄を過ぎても，まだ開腔し ていないものが相当数 $(17.5 \%)$ あり,さらに精子を確 認しても，受胎しないものが相当数認められた。 . 


\section{4. 性周期}

腔垢像に関しては，検索した30匹の本邦産ハタネズミ のうちで, 連続角化像を示す個体や, 不規則に角化細胞 像を示す個体などが認められたが，明膫なパターンを示 す個体は 1 例も観察されなかった。これに対し，ハンガ リー産では，ラットのように規則的な周期を示すものは なかったが，30匹中23匹が $6 〜 18$ 日周期のパターンを示 し, かつ角化細胞消失後に, 子宮内に卵子が確認され た。さらに, これらの腔垢像変化は, Fig. 6 に示した ように, お扔むね, 発情前期 (Proestrous : Stage I ), 発情期 (Estrous : Stage II), 発情後期 1 (Metestrous 1 : Stage III), 発情後期 2 (Metestrous 2: Stage IV) 拈よび発情間期 (Diestrous: Stage V)の 5
期に区分することが出来た $[1,2,10,11]$ 。

5. 初産日齿

Fig. 7 にハンガリー産と本邦産八タネズミの初産日 龄の分布を示した。前者では，60～69日に初産するもの が最も多かった。後者の初産日秢は，130〜139日に最も 多く分布を示し，全体的に，ハンガリ一産のそれよりも はるかに遅かった。

6. 出産の反復性

本邦産拈よびハンガリー産ハタネズミは室内で通年繁 殖が可能である。Fig. 8 にハンガリ一産の“一夫一婦 同居方式”による反復出産にともなら母体重の变化を示 した。交尾後14日目前後には，妊娠の有無が判定しうる ほど，母体重が増加する。連産中の体重変化は規則正し

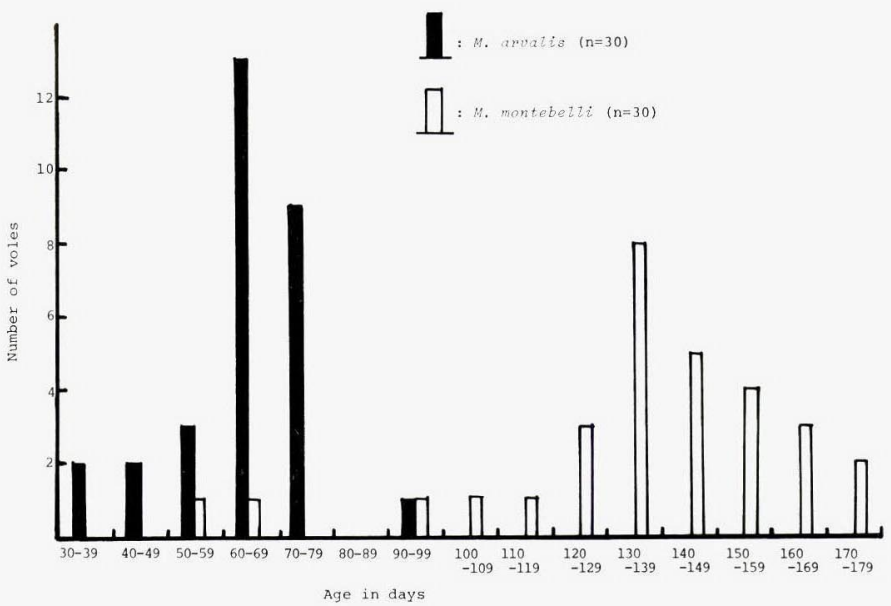

Fig. 7. Distribution by age at the first birth in $M$. montebelli and $M$. arvalis Pallas

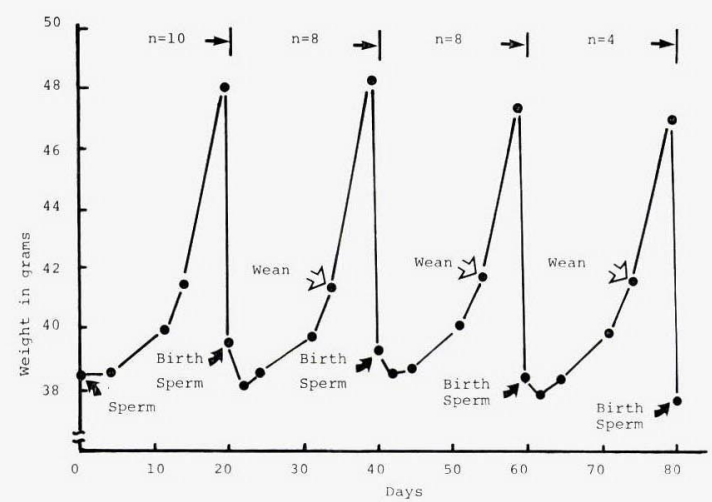

Fig. 8 Changes of body weight in $M$. arralis during their continuous births

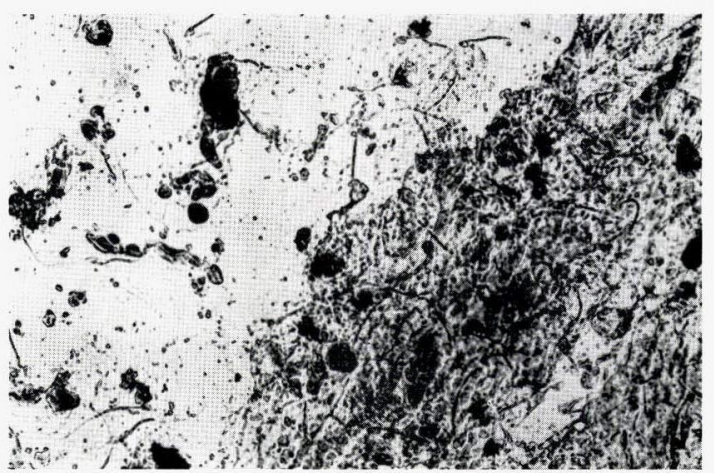

Fig. 9 Vaginal smear of Microtus arvalis Pallas, photographed 30 minutes after birth. Sperms already appear. $100 x$ 


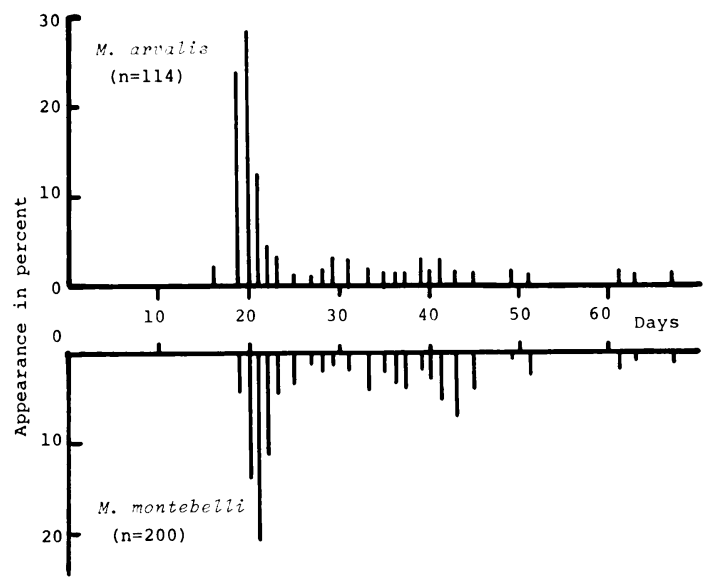

Fig. 10. Distribution by delivery interval in M. montebelli and $M$. arvalis Pallas
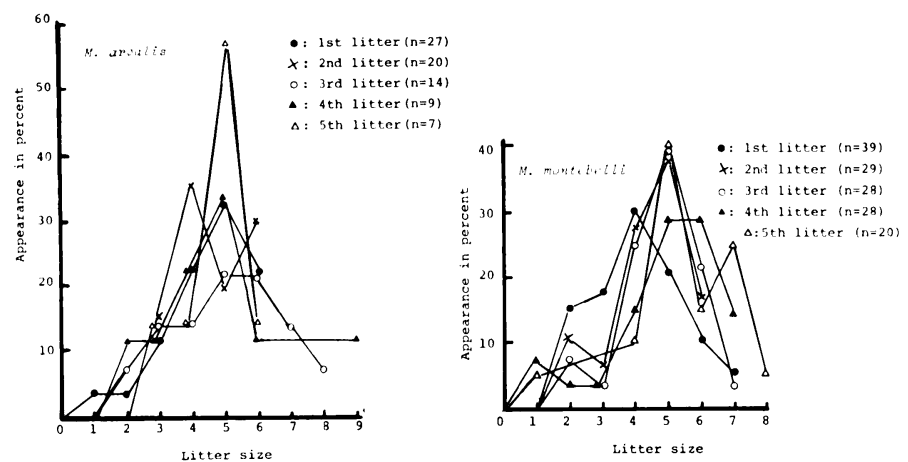

Fig. 11 Litter sizes in M. montebelli and M. arvalis Pallas

く20日周期を描いている。これは後分婏発情時に雄と交 尾した結果であることが, 腔垢中の精子の存在によって 確かめられた (Fig. 9)。このよらな連産の傾向は, 本 邦産よりも，ハンガリ一産の方がより高い頻度で見られ た (Fig. 10)。

\section{7. 産仔数}

Fig. 11 に本邦産とハンガリ一産ハタネズミの産仔 数を示した。平均産仔数は前者で $4.65 \pm 1.39$, 後者で $4.75 \pm 1.40\left(F_{8} \sim F_{13}\right)$ であった。最大産仔数は本邦産 で 9, ハンガリー産で11であった。

以上のように本邦産とハンガリ一産ハタネズミとで は, 生物学的および䌘殖学的に著明な相違が認められ た。これら両種の特性, 相違点を整理すると, Table 2 の通りである。

\section{考察}

本邦産野生ハタネズミの室内繁殖は，必ずしも容易で はないが, 室内繁殖に成功した飼育群においても, その 繁殖成績については, 初産日路令の遅延, 産仔数の僅少な

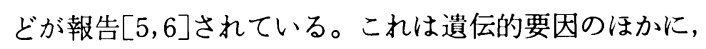
環境的要因，とくに草食動物としての特性に適合しない 飼料を給与したことが主要な原因の一つではなかららか と思われる。著者らは本邦産野生ハタネズミを捕獲し, 種々の線維含有飼料を給与し, 飼育を試みた結果, 給与 飼料の種類により消化管内微生物そうならびに発醉状態 が異なり, 適切な高線維飼料の給与により, それらは改 善されるとともに $[12,13,14]$, 室内繁殖も比較的容易に 
Table 2. Comparison of biological data between $M$. montebelli and M. arvalis Pallas

\begin{tabular}{|c|c|c|}
\hline & M. montebelli** & M. arvalis Pallas*** \\
\hline Origin & $\begin{array}{l}\text { Wild voles, Okekawa, } \\
\text { Saitama, Japan (1977) }\end{array}$ & $\begin{array}{l}\text { Vole colony (F8-10) in La- } \\
\text { boratory for Biology of } \\
\text { Rodents, Hungary (1979) }\end{array}$ \\
\hline No. of chromosomes & $2 \mathrm{n}=30$ & $2 \mathrm{n}=46$ \\
\hline \multirow[t]{2}{*}{ Adult weight } & 今 50-64g & ๙ $36-49 \mathrm{~g}$, 우 $32-38 \mathrm{~g}$ \\
\hline & 우 $38-45 \mathrm{~g}$ & $(25-33 g, \quad 22-30 g)^{*}$ \\
\hline Weight of new born & $2 \cdot 4-3 g$ & $1.8-2.4 \mathrm{~g}$ \\
\hline Estrous cycle & Not identified & 6 to 18 cyclic days \\
\hline Type of ovulation & Copulatory ovulator $\sharp$ & Spontaneous ovulator \\
\hline Mating system & $1: 1$ & $1: 2-5$ is also possible \\
\hline Age of the first birth & $\begin{array}{l}136 \pm 26.1 \text { days } \\
(58-175 \text { days })\end{array}$ & $\begin{array}{l}64.1 \pm 18.6 \text { days } \\
(34-92 \text { days })\end{array}$ \\
\hline Gestation period & 21 days (18-22 days) & 20 days (16-22 days) \\
\hline Average litter size & $4.65 \pm 1.39$ & $4.75 \pm 1.40$ \\
\hline
\end{tabular}

* Data in Hungary \#Goto and Hashizume (1978)

** Breeding in our laboratory for 3 years (1977-1980)

*** Sib mating $(\mathrm{F} 10+5)$ in our laboratory for 2 years (1979-1980)

なることを認めた。とくに，本動物の栄養生理的特性を 考慮しつつ, 実験動物学的立場から, 草食動物用ペレッ トと細切したへイキューブおよび給水により飼育する方 式を考案し，きわめて良好な成績を得た。この点につい て, 八タネズミの室内飼育に既に成功している後藤ら は，当初野菜くずとマウス用ペレットで飼育していた が，その後栄養学的検討を加え，草食動物としての飼料 給与を試みている $[5,18]$ 。しかしその方法は，な拈典型 的な草食性実験動物としてのハタネズミに適合した飼料 メニューならびに組成であるとは考えにくい。またハン ガリーゲッ歯類生物研究所では，ラット用ペレットと野 菜，または牧草のみ[21]で飼育され，水はとくに与えて いなかった。ハンガリー産は, Table 2 から分るよう に, 当研究室へ導入してから, 栄養状態が改善され, 八 ンガリーで22〜33 g であった群が，当研究室飼育群では 同週齡で32〜 49 g と体重が著しく増大している。しかし ながら, ハタネズミの室内飼育の歴史は未だ浅く, 草食 動物用ペレットとへイキューブを併用するという著者ら の飼料メニューも実験動物用飼料としては未完成のもの であり，さらに草食性実験動物としてのハタネズミの栄 養条件に適合した新しい高線維含有ペレットを製作し， このペレット単独による飼育法を確立すべく, 目下のと
ころ, 種々改善を加え, 検討を行っている。

つぎに，繁殖成績に関しては，ハンガリ一における成 績が報告されていないので比較できないが，当研究室に 扣けるハンガリ一産由来ハタネズミは, 初産日齢, 産仔 数などの点でマウスに近い成績を示し，大量生産を行う ことも可能と思われる。いっぽう, 毛色の点では, 当研 究室で継代繁殖しているらちに, Fig. 2 のようなwhite spotを持つものが現われ，世代を重ねるにつれて，こ の white spot が大きくなることが認められた。

本邦産の繁殖上の問題としては, 初産日齢がハンガリ

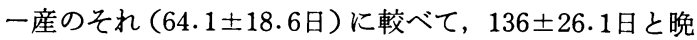
熟であることがあげられるが，それでも後藤の飼育群に 打ける報告[5]の本邦産 2 代における $338.8 \pm 165.4$ 日， 6 代に打ける $186.8 \pm 96.2$ 日よりも，著者らの飼育群の 方が若い初産日齢である。最近, 当研究室で飼育してい る 1 ペアーから, 初産日齢が35〜40日のものとか, 産仔 数が 5 〜 匹の家系が出現しているので, これを種親と して育種巽抜してゆくことなどを合せ考えると，本邦産 の繁殖能力もさらに改善されるものと思われる。

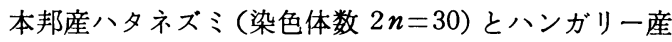
八タネズミ(同 $2 n=46$ ) とは染色体数も大きく異なり， 外観も多少違っているにもかかわらず，相互間での交尾 
は可能であったが，交雑種の作出には成功しなかった。 しかしこの性質を利用すれば，受精や受胎着床などの繁 殖機構を知る上で 重要な材料となる 可能性が考えられ る。八タネズミの繁殖上の特性として，一夫一婦同居方 式で連産の可能なことがあげられるが，この連産は，八 ンガリ一産において，より規則的である。八タネズミで は後分娩発情および追いかけ妊娠が認められるが, 少な くともハンガリ一産においては, マウスやラットで一般 に言われているような受精卵の着床遅延は上述の同居方 式では認められなかった。現在, 八タネズミの平均産 仔数は, Table 2 で見られるよらに, 本邦産の無作為交 配群で4.65土1.39匹，ハンガリ一産の兄妹交配群 ( $\mathrm{F}_{8}$ 〜 $\mathrm{F}_{13}$ ) で 4.75土1.40 匹で, 普通のマウスより少ないが, 哺乳期間は14日で十分離乳できることから，連産による 母体の体力消耗も少なく, 約20～21日の間隔で連産する ため，親一匹当りの生産効率はそれほど悪くはない。た だし，ハンガリ一産八タネズミの無作為交配群では, 産 仔数が 5 〜 匹で連産するものが比較的多く, 今後さら に良好な家系の確立されることが期待される。さらに大 量生産といら観点からいえば, マウスなみの交配方式, すなわち雄 1 匹, 雌 3 匹同居交配が望まれるが, 現在, ハンガリ一産ハタネズミでは,この方式で妊娠し, かつ 離乳にまで至る例も観察されている。1つの大きなケー ジ内で雄 1 匹，雌 5 匹で30匹出産し，24匹離乳したとい 5記録もあり, 今後, いわゆるマルチ交配方式により, 本種の大量生産も可能になってくるものと思われる。

いっぽう, 萬田[19]は, ゴールデンハムスターが草食 性であることに着目し，この動物の栄養生理学的検討を 行った結果, 粗飼料の生物学的評価に本動物が有効であ ることを報告した。しかし，ゴールデンハムスターは， 通常は, マウス, ラットと同様に線維分の少ない飼料で 長期にわたって育種繁殖されて来ているので, にわかに 線維分の多い飼料を給与しても, 草食動物としての本来 の特性を充分に備えているかどらか疑問が持たれる。こ れに対して，著者らの育成している本邦産ハタネズミは 最初から草食動物としての飼料を給与しており，また八 ンガリ一産も入手以来, 同じ草食動物用の飼料を給与し て来ているので, その特性を明らかに維持しており, 両 種とも草食性家畜用の実験動物として期待できる。また 繁殖上の現象についても, きわめて興味ある特徽が恝め られており,さらに同じ Microtus に属しながら， $M$. montebelli と M. arvalis とは生物学的にも, 繁殖学 的にも著しい相違が認められ，これらの面での研究にも 利用できる可能性が充分考えられる。今後, それぞれの
特性をさらに究明し, 研究者の要望に答えられる草食性 小型実験動物として改善育成に勉めたい。

\section{要 約}

八タネズミ(Microtus species) は，草食動物として の特徵をもつ小型実験動物としてきわめて有用である。 著者らは本邦産野生の M. montebelli を起源とする八 タネズミ拈よびハンガリーに棲息する M. arvalis（ハ ンガリーゲッ歯類生物研究所飼育群）由来のハタネズミ の実験動物化に努め, その特徵, 飼育方法および繁殖成 績について検討を加えた。すなわち，高線維含有飼料を 給与することにより，野生ハタネズミを比較的容易に室 内繁殖させることが出来るようになった。

M. arvalisの染色体数は $2 n=46$ であり, M. montebelli の $2 n=30$ とは異っていた。本動物は多発情動物 で，出産当日に後分婏発情がおこり，一夫一婦同居方式 による飼育では，授乳による受精卵の着床遅延はほとん ど見られず，その結果，20２1日の間隔で連産するもの が比較的多かった。胵垢像に関しては, 本邦産八タネズ ミは明瞭なパターンを示さなかったが，ハンガリ一産八 タネズミでは，検査した30匹の中，23匹が $6 〜 18$ 日の周 期を示した。

本邦産ハタネズミとハンガリ一産ハタネズミとでは, 生物学的にも，繁殖学的にも著明な相違が認められた。

本研究に際し，ハンガリ一産ハタネズミを分与された ハンガ リーゲッ歯類生物研究所の E. Nikodemusz 博土および本邦産 八タネズミの生態に関して, 御助言を頂いた 農林水産省家畜衛 生試験場 後藤信男博士に深く謝意を表する。

\section{文献}

[1] Asdell, S. A. (1964). Patterns of mammalian reproduction. 2nd ed, pp. 298-307, Cornell Univ. Press, New York.

[2] Clulow, F. V., and Mallory, F. F. (1970). Oestrus and induced ovulation in the meadow vole, Microtus pennsylvanicus. Reprod. Fert., 23, 341-343.

[ 3 ] Cowan, R. L., Long, T. A., and Jarret, M. (1968). Digestive capacity of the meadow vole (Microtus pennsylvanicus). J. Anim. Sci., 27, 36.

[4] Elliot, F. C. (1963). The meadow vole (Microtus pennsylvanicus) as a bioassay test organism for individual forage plants. Quart. Bull., 46, 58-72.

［5]後藤信男 (1975). 八タネズミ. 実験動物の飼育管理と手 技, pp. 280-289, 今道友則 監修, ソフトサイエンス社, 東京.

［6］後藤信男・橋詰良一・崔郁虎 (1977). 八タネズミの 産仔 数と胵垢像について. 哺乳動誌, 7, 75-85. 
［7］後藤信男・橋詰良一 (1978). 八タネズミ (Microtus montebelli) の排卵様式. 哺乳動誌, 7, 181-188.

[8] Hartke, G. T., Leipold, H. W., Huston, K., Cook, J. E., and Saperstein, G. (1974). Three mutations and the karyotype of the prairie vole. White spotting, polydipsia, and muscular dystrophy in Microtus ochrogaster. J. Hered., 65, 301-307.

[9] Keys, J. E. Jr., and Van Soest, P. J. (1970). Digestibility of forage by the meadow vole (Microtus pennsylvanicus). J. Dairy Sci., 53, 1502-1508.

[10］北 徳・小林英文・猪 貴義・仲田包著 (1979). チャイ ニーズハムスターの発情周期にともなう胵垢像の変化. 実験動物 28, 11-16.

[11］北 徳・西川 哲・猪 貴義・山上貢司 (1979)，妊娠于 ヤイニーズハムスターにおける腟粘液分泌と腟垢像の変 化. 実験動物, 28, 365-372.

[12] Kudo, H., Oki, Y., and Minato, H. (1979). Microtus species as the laboratory animals. I. Bacterial flora of the esophageal sac of Microtus montebelli fed on different rations and its rerationship to the cellulolytic bacteria. Bull. Nippon Vet. Zootech. Coll., 28, 13-19.

［13］工藤 博 (1980). 草食性ハタネズミにおける 発酵生産物 の産生, 利用および 実験的糖尿病一ケトン 尿症に関する 研究. 栄養生理研究会報, 24, 17-34.

[14] Kudo, H., and Oki, Y. (1981). Fermentation and VFA productions in the esophageal sac of Microtus montebelli fed on different rations. Jpn. J. Vet. Sci., 43, 299-305.

[15] Lecyk, M. (1962). The effect of the length of daylight on reproduction in the field vole (Microtus arvalis Pall.). Zoollogica poloniae, 12, 189-221.

[16] Lee, C., Inskeep, E. K., and Horvath, D. J. (1968).
Ovulation in meadow vole(Microtus pennsylvanicus). J. Anim. Sci., 27, 35.

[17] Lynch, G. P., and Keys, J. E. (1968). Nutritional studies using the meadow vole (Microtus pennsylvanicus). J. Anim. Sci., 27, 34.

［18］万田富治・後藤信男（1976）. 牧草消化能力に関する八厶 スターとハタネズミの比較研究. 日本草誌, 22,52 .

[19］万田富治 (1979). 八ムスターの栄養生理と粗飼料の利用 特性. 栄養生理研究会報, 23, 111-128.

[20] Mammalian chromosomes Newsletter. (1967). 8(4), 283.

[21] Nikodemusz, E. (1975). The method of intragastric administration of fluid to field vole (Microtus arvalis Pallas). Z. Versuchstier, 17, 1-3.

［22］ 小原嘉昭・後藤信男（1980），ハタネズミ Japanese field vole (Microtus montebelli) 消化管における揮発性脂肪 酸産生と消化管および肝組織におけるその 消費。日畜会 報, 51, 393-396.

[23] Schnedl, W., and Czacker, R. (1974). Centromeric heterochromatin and comparison of G-banding in cattle, goat, and sheep chromosomes (Bovidae). Cytogenet. Cell. Genet., 13, 246-255.

[24] Schnedl, W., and Schnedl, M. (1972). Banding patterns in rat chromosomes (Rattus norvegicus). Cytogenetics, 11, 188-196.

[25] Shenk, J. S., Elliot, F. C., and Thomas, J. W. (1971). Meadow vole nutrition studies with alfalfa diets. J. Nutr., 101, 1367-1372.

[26] Shenk, J. S. (1976). The meadow vole as an experimental animal. Lab. Anim. Sci., 26, 664-669.

[27] Yamanaka, H. (1977). The possibility of cattle chromosome classification, identified by G-banding patterns. Jpn. J. Vet. Res., 25, 52-58. 